\title{
Introduction: Comparing Foucault: Cultivations of Gnosis and Technologies of the Self
}

\author{
Claire Fanger \\ Department of Religion, Rice University, Houston TX, USA \\ cfanger@rice.edu
}

The essays gathered here were originally presented at a session on "Care of the Self in Esoteric Traditions" at the Annual Meeting of the American Academy of Religion in 2016. The papers concern different religious cultures and time periods, but are bound together thematically by their attention to the ritual crafting of experiences of gnosis in tandem with attention to Foucault's ideas about technologies of the self. Their interest derives indeed from how closely linked the experiences of gnosis are in the texts under examination to an idea of the crafting of particular selves in transit from one state of being to another: from, for example, a sinful self to a self rectified in the eyes of God; from an ordinary unmagical self to a conjurational self; or from a self that is still a novice to an adept self, with powers acquired through experience simultaneously ritual, intuitive, and supernormal.

In explicating how "gnosis" will be understood for the purposes of this special issue, I want to start with two entries from Thayer's Greek-English Lexicon of the New Testament. ${ }^{1}$ The first entry is for the noun "gnosis," and second for the correlated verb, "ginosko." The words "gnosis" and "ginosko" mean roughly "knowledge" and "to know," but they emphasize knowledge derived from first-hand experience - working knowledge, hand-knowledge as opposed to head-knowledge:

gnốsis (a feminine noun derived from ginốskō, "experientially know") functional ("working") knowledge gleaned from first-hand (personal) experience, connecting theory to application; "application-knowledge,"

1 Joseph Henry Thayer (1828-1901) was a New Testament scholar who published his Greek lexicon in the 188 os, expanding on W.C. Wilkes Clavis Nova Testamenti, originally published in Latin in 1841. Thayer's dates coincide with the expansion of the word "gnosis" in English, on which I will comment later. 
gained in (by) a direct relationship. ginốskō - properly, to know, especially through personal experience (first-hand acquaintance). Ginốskō ("experientially know") is used for example in Lk 1:34, "And Mary [a virgin] said to the angel, "How will this be since I do not know (ginốskō = sexual intimacy) a man?"2

The reference to Mary who "does not know a man" makes it startlingly clear what an intrinsically embodied concept is implicated in the usage of this word; it is a knowing embedded in the body and its sensorium.

In other usages specific to the New Testament we find a range of meanings for "gnosis" including "knowledge of God, such as is offered in the gospel" (2 Corinthians 2:14) and "the general knowledge of the Christian religion" (Romans 15:14; 1 Corinthians 1:5). It can also mean "the deeper, more perfect and enlarged knowledge of this religion, such as belongs to the more advanced" (for example, among an array of examples 1 Corinthians 12:8; 1 Corinthians 13:2, 8). ${ }^{3}$

These biblical instances are relevant to the English uses of the word, which, according to the Oxford English Dictionary, do not begin before the eighteenth century, and become more frequent through the nineteenth when Thayer was working on his lexicon. A link to the Christian context that is so important for Thayer is still explicit in the Oxford English Dictionary definition of "gnosis": "knowledge (in Christian writers esp. a higher knowledge of spiritual things). A special knowledge of spiritual mysteries. Often with reference to the claim to such knowledge made by the Gnostics." ${ }^{\prime}$

More contemporary dictionary definitions of "gnosis" drop references to an explicitly Christian context, though the ascribed senses of "revealed truth" and "spiritual mysteries" remain. The Gnostics also remain as a touchstone. For illustrative purposes I draw in two recent English dictionary definitions: "Gnosis: Intuitive apprehension of spiritual truths, an esoteric form of knowledge sought by the Gnostics," ${ }^{5}$ or "supposedly revealed knowledge of various spiritual truths, esp that said to have been possessed by ancient Gnostics." ${ }^{\prime}$

When detached from its New Testament context, the idea of "[supposedly] revealed knowledge" or "spiritual truth" found in these last two definitions might sound more like an experience of sudden illumination, a bolt from

2 Thayer, s.v. "gnosis" and "ginosko."

3 Concordance citations in Thayer, s.v. "gnosis."

4 Oxford English Dictionary s.v. "gnosis."

5 American Heritage Dictionary, s.v. "gnosis."

6 Collins English Dictionary, s.v. "gnosis." 
above that is uniformly possible and available to all regardless of time period or religious or cultural embeddedness. It sounds much less like something that is cultivated through habit, internalized by study, or sought from a teacher or adept, though the New Testament includes usages like these. Discussing the array of different ways that gnosis is represented in Early Christian literature, April DeConick has noted how, for some, "[g]nosis is associated with visionary experiences, ecstasy, and alterations of consciousness, as well as ritual technologies and contemplative practices to achieve these altered states"; she adds that "[s]piritual transformation and salvation often accompany gnosis, since the direct experience of God or communion with him was believed by many people in antiquity to alter them enough to liberate them from the material world, if not immortalize or deify them."

In this special issue, the experiential forms of gnosis under study are not sudden unexpected theophanies, bolts from the blue, but rather theophanies for which selves are rigorously prepared; they are experiences brought about through a set of sustained habitual exercises or ritual practices. They do certainly constitute, at the same time, a knowledge that is "revealed" to the experiencer, and they bring about something arguably to be understood as revealed spiritual (or at least cosmic) truths. Experiences of gnosis are, as well, experiences that fundamentally shift or change the sense of what constitutes self for those that have them. Readers may keep in mind the common sense of "gnosis" as revealed knowledge, but I lean on the original Greek context as a reminder that at its point of origin, and throughout these pieces, the word "gnosis" suggests an applied knowledge, a knowledge that comes about in the context of regular embodied ritual acts.

It is also this embodied sense of the word "gnosis" that brings us closer to Foucault and to his understanding of practices of "care of the self," which, not unlike the advanced Christian "gnosis" referenced in Thayer's lexicon, are concerned with self-transformation. In Foucault's words, technologies of the self "permit individuals to effect by their own means or with the help of others a certain number of operations on their own bodies and souls, thoughts, conduct, and way of being, so as to transform themselves in order to attain a certain state of happiness, purity, wisdom, perfection, or immortality." ${ }^{8}$ The four articles in this issue all reflect on the relation between this idea of technology of self and experiences of gnosis. Each, however, deals with a different religious tradition in a different time period, and in a different cultural setting.

7 DeConick, "Gnosis/Gnosticism."

8 Foucault 1988, 18, my emphasis. 
My article takes as its point of departure the account of a vision of Christ recorded by the fourteenth-century French monk, John of Morigny (fl 13001315). It is a case study set firmly in the medieval Christian world. In the first part I outline some of the ways in which Foucault's thought both is and is not "theological." I note that since Foucault draws on Christian models, John's visionary practice might seem to be almost a too-perfect prototype of the self-care Foucault was interested in, since John's vision profoundly involves repentance and confession.

Yet the results of the analysis are unexpected. The vision, which is induced by John's own prayer practice, involves a very odd narrative of Christ appearing in penitential garb and asking to confess his own $\sin$ to John of Morigny. I demonstrate that it is only possible to make sense of this vision by looking at the ways Christ acts as an intimate mirror of John's self, reflecting the appropriate stance and penitential practice for John to follow to reconcile himself with God.

The second article by Joshua Gentzke deals with Jacob Böhme (1575-1624), who emerged from a Lutheran background to produce mystically inclined writings of increasing theological novelty. The article begins by noting the conflicting, evolving early Protestant accounts of what actually happens in the sacrament of communion: in what sense does the bread "become" flesh? And in what way can it imbue grace on the person who ingests it? The theologians preceding Böhme, whether or not they understood the wafer to contain the real presence of Christ, argued in greater and lesser degrees for the importance of faith in the effectiveness of the sacrament.

Böhme makes a novel and extreme leap in moving the entire drama of the Eucharistic sacrament to a location interior to the person. The process is likened by Böhme to a form of alchemy: the sacramental transformation happens when the soul, like an alchemical fire, consumes the bread which is the wisdom of God. God becomes again incarnate in the faith-flesh of individual Christians, who are themselves simultaneously divinized. As in the case of John of Morigny, the experiential gnosis described by Böhme shows God and the self to be deeply and inextricably associated; though if John's vision shows God brought down to a more human level through sin, Böhme shows the human raised up through faith.

Stephen Wehmeyer's article, the third in the suite, ventures outside the Christian tradition, bringing together material from the folklore studies of Harry Middleton Hyatt (1896-1978) with the ethnographic memoir of Zora Neale Hurston (1891-1960). Both of them researched African-American Hoodoo and Conjure traditions in the first half of the twentieth century. The article makes a case for the existence of rituals of initiation in these traditions that conform to the Foucauldian understanding of a technology of self. 
These initiatic rituals were somewhat underrepresented in the massive oeuvre of Hyatt, evidently because he did not believe in them - perhaps evidence must fall in the category of the superstitious rather than the religious to count as folklore. Hurston's study methods were different. Central to the argument is an elaborate ritual of initiation described by Hurston, which she herself undertook, called the ritual of the "black cat bone." The article suggests that this was an initiatic ritual, and that Hurston was engaged with the formation of what Wehmeyer calls a "conjurational self," a self with special powers.

Finally, in the fourth article, Erik Davis looks at the American writer of esoteric fiction and non-fiction, Robert Anton Wilson (1932-2007). Wilson engaged a very mid-century modern form of gnosis, in that he propounded practices involving hallucinogens in crafting attempts to break free of what he thought of as normative "reality tunnels," alongside and in company with Timothy Leary and Terence McKenna. But to what extent does this constitute a crafting of "self" along the ethical lines imagined by Foucault? The problem of what constitutes "gnosis" is acute also, since Wilson, while experiencing many visions inhabited by hyperreal gods and demons, patently does not believe in any of them.

Davis argues plausibly that Wilson's cosmic and ethical stance resembles Pyrrhonian skepticism: wisdom involves suspending judgment about such things. Though it may appear as merely a kind of anarchic practice of spiritual freedom, Wilson's "technology of self" is in fact a practice of resisting pressure to resolve his own experiences of gnosis into the socially proffered frameworks either of faith or knowledge. Transcendence is thus located in the dance of "maybe logic" (as Davis puts it) between materialism and mysticism.

These four case studies are different in the kinds of practices they involve, in the aims of those practices, and in the end result of the practices on the self. They describe not just different kinds of self-care, but also different kinds of selves. There are two important questions this poses: 1) Do Foucault's ideas retain coherence and meaningfulness when used to evaluate practices completely outside the logic of the Hellenic or Christian sources from which he derived them? Are they even thinkable when connected for example to African-American Conjure, or to the maverick use of hallucinogens by Wilson and Leary? 2) When connected to experiences of gnosis in Christian cultures, do Foucault's ideas yield interesting and unexpected readings of these phenomena?

To both questions I think the answer suggested by these articles is yes: Foucault is interesting to think with. The four essays point to ways that the Foucauldian paradigm might need expanding or adjusting to inquire into the formation of non-Christian or non-Catholic selves; yet all of the contributions are revealing as they follow their own paths into multiple forms of gnosis and self-crafting. 


\section{Bibliography}

American Heritage Dictionary of the English Language, Fifth Edition. 2011. Houghton Mifflin Harcourt Publishing Company. Accessed 13 Jan. 2021. https://www.thefree dictionary.com/gnosis.

Collins English Dictionary: Complete and Unabridged, Twelfth Edition. 2014. Harper Collins Publishers. Accessed 13 Jan. 2021. https://www.thefreedictionary.com/ gnosis.

DeConick, April D. “Gnosis/Gnosticism." Brill Encyclopedia of Early Christianity Online edited by David G. Hunter, PaulJ.J.vanGeest, and Bert JanLietaert Peerbolte. Accessed May 5, 2021. doi: http://dx.doi.org/10.1163/2589-7993_EECO_SIM_oooo1439.

Foucault, Michel. 1988. Technologies of the Self: A Seminar with Michel Foucault. Ed. Luther H. Martin, Huck Gutman, Patricia H. Hutton. Amherst: University of Massachusetts Press.

Oxford English Dictionary, Compact Edition. 1971. 2 Vols. Oxford: Oxford University Press.

Thayer, Joseph Henry, Thayer's Greek-English Lexicon of the New Testament. Electronic Database. Copyright (C) 2002, 2003, 2006, 2011 by Biblesoft, Inc. Accessed 13 Jan. 2021. https://biblehub.com/greek/1o97.htm. 